\title{
The Design Canvas Platform on the Arena-O Startup Venture
}

\author{
Muhammad Nuraga Lazuardy Ramadhan \\ MieAja \\ mnuragadhan@gmail.com \\ https://doi.org/10.37715/rmbe.v1i2.2414
}

\begin{abstract}
This study aims to plan a suitable business model using the Platform Design Canvas for the Arena-O Startup business. This study uses a qualitative method. Data collection was carried out by in-depth interviews and documentation study. The informants in this study represent the respective actors of the platform business, namely producers, consumers, and platform owners. The results of this study describe the business model of a sports field reservation startup called Arena-O, which is detailed using thirteen blocks on the Platform Design Canvas. Thus, thirteen blocks in this reseacrh are platform owners, stakeholder platforms, enabling services, empowering services, other services, core value proposition, ancillary value proposition, infrastructure and core components, transactions, channels \& contexts, partners, peers producers, peers consumers. This research can find out the visualization of Arena-O's business processes from upstream to downstream. Then from these results, the managerial implications of Enabling Services, Other Services, and Partners indicators can be applied to Arena-O so that it can develop.
\end{abstract}

\section{Keywords - Platform Business, Startup, Platform Design Canvas.}

\section{Introduction}

The development of technology, the broader reach of $4 \mathrm{G}$ internet, and the cheaper technology devices have made internet users in the country grow rapidly. With the increasing number of Base Transceiver Station (BTS) towers built by operators and cellular service providers, the construction of the Palapa Ring fiber optic cable network will improve internet services in Indonesia, especially the eastern part. Indonesia has the highest number of startup unicorns in Southeast Asia, followed by Singapore, the Philippines, and Vietnam. Unicorn is a term that refers to startups or start-ups that have a valuation value of more than US \$ 1 billion to US \$ 10 billion. The growth of internet users, the number of unicorn startups in Indonesia, and the use of the internet in Indonesia have spurred startups to emerge, making Indonesia the fifth-ranked country for startups in the world with 2,074 companies. According to East Ventures, three startup fields are prima donna in 2019 namely fintech, education, and health. In the health sector, especially sports, the interest of the younger generation or young professionals is very high. This can be seen from the Alvara Research Center survey results, which showed that in most of the millennial generation (aged 20-35 years) as many as 72.9\% of respondents claimed to like exercising.

Researchers see an opportunity amid rapid technological advances and the high public interest in sports. Researchers decided to create an online platform that can make it easier for sports fans to order sports fields online. Arena-O is a platform that helps sports fans to book sports fields in Surabaya online. Arena-O's initial focus was to make it easier to order futsal, basketball, and badminton sports fields. In the process of pioneering Arena-O requires careful business model planning to generate value for both consumers and good value for the company. It is hoped that Arena-O can provide value or benefits for consumers and companies.

\section{Literature Review}

2.1. Previous Research

The first research was conducted by Qur'ani and Khairunnisa (2018), the study aims to find out the description of the Laundry Papin business model when viewed with the Business Model Canvas and to find out the business model to develop an appropriate strategy to be applied to Laundry Papin. Research analysis was carried out by BMC and SWOT analysis.

The second study was conducted by Zuhri and Melinda (2018), this study aims to describe the Business Model Canvas (BMC) in the CV cracker manufacturing company. T in Sidoarjo. This study used descriptive qualitative method. The research analysis uses a value proposition design canvas to find value propositions fit, namely problem-solution fit and product market-fit. This study uses IDEO's three lenses of innovation which include desireability, feasibility, and viability tests. The result of this research is a business model canvas that includes customer segments, value propositions, channels, customer relationships, revenue streams, key resources, key activities, key partnerships, and cost structure for the CV cracker company. Q. The relationship with this 
research is the similarity of qualitative research methods and how the Business Model Canvas can help company owners know the picture of the business being involved.

The third research was conducted by Ju et al. (2016), the research aims to develop an IoT business model. This study used descriptive qualitative method. Data was collected through in-depth interviews and documentation studies. The research analysis uses the Business Model Canvas to understand and analyze IoT activities divided into three groups, namely smart home IoT, industrial IoT, and transportation IoT. The connection with this research is the similarity of research methods and creating a relatively new business model canvas.

The fourth research conducted by Sort and Nielsen (2018), the study aims to investigate how entrepreneurs market their business opportunities to business angels in the investment process. This study used descriptive qualitative method. Data was collected through in-depth interviews and documentation studies. The research analysis uses a business model canvas as a mitigation framework to assist entrepreneurs in communicating and compiling the information desired by business angels. The result of this research is that BMC can support easier communication, information and understanding of investment. In addition, BMC can identify a series of problems that arise in the investment process. The relationship with this research is the similarity of research methods.

\subsection{Digital Startups}

According to Blank (2010), Startup is a company formed to seek a scalable and repeatable business model. According to KBBI, digital is dealing with numbers for specific calculation systems. The word digital comes from the Greek digitus, which means finger. The word digital is synonymous with the modern era where technology has developed and is very advanced thanks to computers and internet networks. So digital startups are companies that use technology to find scalable and repeatable business models.

\section{3. $\quad$ Platform Bussiness}

According to Kumar (2018), a business platform is a business that facilitates many parties. These business owners have the infrastructure that facilitates transactions. The business platform also adds network value.

\subsection{Platform (Strategy)}

Platform (strategy) according to the Platform Design Toolkit handbook 2019, is a strategy executed by "platform builders" who wish to mobilize and assist the ecosystem in creating value, to capture this share of value. Platform strategy comprises a combination of elements: narrative, technology, rules, channels, context, enabling services, protocols, and more.

\subsection{Ecosystem}

According to the Platform Design Toolkit handbook 2019, Ecosystem is a set of entities that play in a context (e.g. sector, industry, market, organization) interacting and exchanging value, utilizing resources, and generating results. We often use "system" as an alternative to "ecosystem". Note that contexts often overlap and ecosystem boundaries are difficult to define.

\subsection{Entity}

According to the Platform Design Toolkit manual 2019, Entity is an individual, economic and social actor with a specific purpose. It can include a person, organization, institution, or team.

\subsection{Role}

According to the Platform Design Toolkit handbook 2019, Role in platform thinking, defining ways of grouping several types of entities into the same category of players. This is primarily based on how much they share their motivation to join, their assets, abilities, and the type of exchange of value that they have. Grouping entities into roles helps you implement platform thinking.

\subsection{Transaction}

According to the Platform Design Toolkit manual 2019, transaction is an interaction between two entities. It occurs within a channel or context and involves an exchange of value between two communications. Transactions are already happening even before the platform strategy is implemented. However, the more channels are well designed to reduce coordination/transaction costs, the more transactions will happen easily. Good transactions are elementary, atomic.

\subsection{Incentive}

According to the Platform Design Toolkit handbook 2019, Incentive is one of the main pillars in designing and using a platform strategy. Usually, incentives have to do with anything that overcomes the pressures of an entity's performance, life goals or produces more comfort for them. The more we understand incentives, the more likely they will embrace the "new rules of the game" embedded in the platform's strategy. 


\subsection{Platform Design Canvas}

Plarform Design Canvas is a development of the Business Model Canvas by Clark et al. (2012) which focuses on business in the form of platforms. The Platform Design Canvas was created by Simon Cicero and the Platform Design Toolkit team in 2019. The Platform Design Canvas can be a compact way to recap the potential of a platform's ecosystem and strategy (a kind of "dashboard") or quickly explore the potential of a platform without diving into more complex processes. In the Platform Design Canvas, there are 13 blocks, each of which is interrelated and includes three related entities, namely impact entities, demand entities, and supply entities. The thirteen blocks are Platform Owners, Platform Stakeholders, Enabling Services (Platform to Partners), Empowering Services (Platform to Peer Producers), Other Services (Platform to Peer Consumers), Core Value Proposition, Ancillary Value Propositions, Infrastructure and Core Components, Transactions, Channels \& Contexts, Partners, Peers (Producers), and Peers (Consumers).

\section{Research Methods}

\subsection{Theoretical Basis}

In this study, the paradigm of post-positivism was used. According to Bungin (2007) post-positivism was born, among others, because:

1. Ontologically, postpositivism is critical realism which views that reality exists according to natural laws, but it is impossible if a reality can be seen correctly by humans (researchers).

2. Methodologically the experimental approach through observation is not enough, but it must use the triangulation method, namely the use of various methods, data sources, researchers, and theories.

3. Epistemologically, the relationship between the observer or researcher with the object or reality under study cannot be separated, as proposed by the flow of positivism.

Post-positivism states that it is impossible to reach or see the truth if the observer is standing behind the screen without being directly involved with the object.

\subsection{Research Methods and Approach}

This study uses a descriptive qualitative research method with a deductive approach. According to Bungin (2007) the descriptive format is heavily influenced by the positivistic paradigm, although this format predominantly uses the phenomenological paradigm. Qualitative descriptive format is generally carried out in research in the form of case studies. Qualitative descriptive format is more appropriate when used to examine problems that require in-depth study, such as problems of consumer behavior of a product, the effect of media on viewers' views on media broadcasts, problems of implementing public policies in society, Etc. According to Bungin (2007), deductive theorization reveals that theory is used as a starting point for answering research questions. In fact, a deductive view guides research by first using theory as a tool, measure, and even an instrument to build hypotheses. According to Yusuf (2016), deductive thinking begins with a theory and ends with a special phenomenon or thing. Based on general knowledge, then specific events are assessed.

\subsection{Method of collecting data}

According to Yusuf (2016), success in data collection is largely determined by the ability of researchers to appreciate the social situation that is the focus of research. The researcher will end the data collection phase when the researcher believes that the data collected from different sources and focused on the social situation under study has been able to answer the research objectives. In this study, the data collection method used interview and observation techniques. The type of interview used is a planned-unstructured interview. The researcher prepares a solid interview plan, but does not use a standard format and sequence so that the informant is more accessible and natural in conveying the social situation being studied. Then the form of observation used is non-participation observer, which is a form of observation in which the researcher is not directly involved in group activities, or it can also be said that the observer does not participate in the activities being observed. In collecting data, the researchers did triangulation. According to Yusuf (2016) training is a technique in data collection to obtain more accurate and credible data findings and interpretations. This type of data collection triangulation used in this study is triangulation with multiple techniques (multiple methods). Triangulation of multiple methods can be interpreted that if at the initial stage information is collected by the interview method, then use other methods such as observation to collect the same information. 


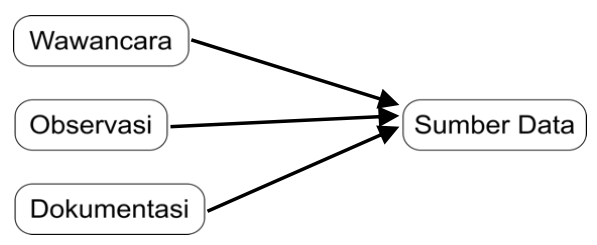

Figure 3.1. Multiple Methods

\subsection{Data analysis}

This study uses group performance analysis and individual experience as well as institutional behavior. According to the book by Bungin (2007, p. 161) group performance analysis and individual experience, as well as institutional behavior are analytical tools used to analyze individual performance and experience as well as institutional behavior to see the outputs generated from these performances, carried out by research objects and informants, and how the research object and informants interpret the performance output. Data analysis in this study was carried out by detailing thirteen blocks on the Platform Design Canvas consisting of platform owners, platform stakeholders, enabling services (platform to owners), empowering services (platform to peer producers), other services (platform to peer consumers), core value proposition, ancillary value propositions, infrastructure and core components, transactions, channels \& contexts, partners, peers (producers), and lastly, peers (consumers) based on the business plan to be created.

To make it easier to fill out the Platform Design Canvas in the Platform Design Toolkit manual, 2019 is divided into three main entity groups, namely impact entities, demand entities, and supply entities.

1. Impact Entities are owners or have authority in a platform. Within the Platform Design Canvas, there are the platform owners and platform stakeholders blocks.

2. Demand Entities are entities interested in consuming the value generated in the ecosystem. Within the Platform Design Canvas, there is the peer consumers block.

3. Supply Entities are entities that are interested in generating value that is consumed in the ecosystem. Within the Platform Design Canvas, there are partners and peer producers blocks.

\section{Result and Discussion}

Arena-O is a platform that helps sports fans to book sports fields in Surabaya online. The data in this study were obtained through interviews with three research subjects, namely one sports fan, one CEO of a technology startup in the lifestyle sector, and one owner of a sports field.

Table 4.1 Summary of interviews with informants.

\begin{tabular}{|l|l|l|}
\hline \multicolumn{1}{|c|}{ Canvas Block } & \multicolumn{1}{|c|}{ Research subject } & \multicolumn{1}{c|}{ Interview result } \\
\hline Platform Owners & $\begin{array}{l}\text { CEO Startup Pathlister } \\
\text { (platform owner) }\end{array}$ & Consists of four owners consisting of CEO, COO, CTO, and CFO. \\
\hline $\begin{array}{l}\text { Stakeholder } \\
\text { Platforms }\end{array}$ & $\begin{array}{l}\text { CEO Startup Pathlister } \\
\text { (platform owner) }\end{array}$ & $\begin{array}{l}\text { The government, be it the Surabaya city government, East Java } \\
\text { Province, and the Republic of Indonesia, directly and indirectly } \\
\text { influence the direction and policies for the sustainability of Pathlister's } \\
\text { business. }\end{array}$ \\
\hline Enabling Services & $\begin{array}{l}\text { Sports field owner } \\
\text { (manufacturer) }\end{array}$ & $\begin{array}{l}\text { Sports field owners want a sales record service and a cashless system } \\
\text { for payment. }\end{array}$ \\
\hline Empowering Services & $\begin{array}{l}\text { Sports field owner } \\
\text { (manufacturer) }\end{array}$ & $\begin{array}{l}\text { Sports field owners want Arena-O to provide online sports field } \\
\text { ordering services and provide sales recording services so that sports } \\
\text { field owners have neat order records every month, thus facilitating the } \\
\text { performance of sports field owners. }\end{array}$ \\
\hline Other Services & $\begin{array}{l}\text { CEO Startup Pathlister } \\
\text { (pemilik platform) }\end{array}$ & $\begin{array}{l}\text { In addition to the website, Pathlister also has iOS application services, } \\
\text { Android applications, WhatsApp for Business, and Instagram to reach } \\
\text { consumers. }\end{array}$ \\
\hline $\begin{array}{l}\text { Core Value } \\
\text { Proposition }\end{array}$ & $\begin{array}{l}\text { CEO Startup Pathlister } \\
\text { (pemilik platform) }\end{array}$ & \begin{tabular}{l} 
Pathlister's vision is to be an inspiration in lifestyle and travel. \\
\hline
\end{tabular} \\
\hline
\end{tabular}




\begin{tabular}{|c|c|c|}
\hline & $\begin{array}{l}\text { Sports field owner } \\
\text { (manufacturer) }\end{array}$ & $\begin{array}{l}\text { Sports field tenants are a segment with an age range of } 10-55 \text { years, } \\
\text { consisting of various professions ranging from school children, } \\
\text { students, and professionals and is dominated by men. }\end{array}$ \\
\hline $\begin{array}{l}\text { Ancillary Value } \\
\text { Proposition }\end{array}$ & $\begin{array}{l}\text { CEO Startup Pathlister } \\
\text { (platform owner) }\end{array}$ & $\begin{array}{l}\text { Pathlister is developing a podcast service called Pathcast and plans to } \\
\text { release a new service called Pathlister Eats to accommodate food and } \\
\text { beverage businesses. }\end{array}$ \\
\hline \multirow[t]{2}{*}{$\begin{array}{l}\text { Infrastructure and } \\
\text { Core Components }\end{array}$} & Sports fans (consumers) & $\begin{array}{l}\text { Prefers to use a mobile application rather than opening } \\
\text { a website because it is more accessible and more concise. }\end{array}$ \\
\hline & $\begin{array}{l}\text { CEO Startup Pathlister } \\
\text { (platform owner) }\end{array}$ & $\begin{array}{l}\text { To run it business Pathlister requires hosting and domain rental for } \\
\text { website and mobile application services. }\end{array}$ \\
\hline Transactions & $\begin{array}{l}\text { Sports field owner } \\
\text { (manufacturer) }\end{array}$ & $\begin{array}{l}\text { According to sports field owners, cashless payment systems such as } \\
\text { OVO can be an attractive option because apart from being practical, } \\
\text { they can also attract customers with their cashback promos. }\end{array}$ \\
\hline \multirow[t]{2}{*}{ Channels \& Contexts } & Sports fans (consumers) & Prefer using mobile applications rather than opening websites. \\
\hline & $\begin{array}{l}\text { Sports field owner } \\
\text { (manufacturer) }\end{array}$ & Sports field owners are interested in cashless payment systems. \\
\hline Partners & $\begin{array}{l}\text { CEO Startup Pathlister } \\
\text { (platform owner) }\end{array}$ & $\begin{array}{l}\text { For Pathlisters who are engaged in travel and lifestyle, their partners } \\
\text { are local agents. }\end{array}$ \\
\hline Peers Producers & $\begin{array}{l}\text { CEO Startup Pathlister } \\
\text { (platform owner) }\end{array}$ & $\begin{array}{l}\text { The producers for the Pathlister platform are hotels, tourism and } \\
\text { experience providers, and transportation providers, both land, sea, and } \\
\text { air. }\end{array}$ \\
\hline Peers Consumers & $\begin{array}{l}\text { Sports field owner } \\
\text { (manufacturer) }\end{array}$ & $\begin{array}{l}\text { Sports field tenants are a segment with an age range of } 10-55 \text { years, } \\
\text { ranging from school children, students, and professionals and } \\
\text { dominated by men. }\end{array}$ \\
\hline
\end{tabular}

\subsection{Platform Owners}

In this study, Platform Owners namely: the "owners" of the platform who have the vision behind the realization of the market, and are ultimately responsible for ensuring that the platform is in production. In this research, Arena-O is the owner of a platform that connects producers (sports field owners) with consumers (sports fans).

\subsection{Platform Stakeholders}

In this study, what is meant by Platform Stakeholders namely: entities that have a special interest in the success or failure of the platform, control platform externalities and outcomes, regulate or exercise rights in platform governance. For now, Arena-O is still using its own funds (it doesn't have investors yet ), but beyond that, policies and regulations from the Surabaya City Government, East Java Provincial Government, and the Ministry of Youth and Sports are the main reference in the operation of Arena-O's business.

\subsection{Enabling Services}

In this study, what is meant by Enabling Services namely: services targeted to help partners generate value from their professional abilities, gain market, opportunity, and visibility to get upgrades. To help Arena-O's producing partners gain a wider market, Arena-O will create a sports tournament that will rent sports fields on a regular basis until the tournament is over. Then consumers will benefit from member promos, namely monthly subscriptions with attractive promos using a cashless payment system. Finally, Arena-O will provide 24-hour admin support to answer consumer questions and sports field reservations complaints.

\subsection{Empowering Services}

In this study, what is meant by Empowering Services namely: services targeted to help fellow producers hone their skills, become better and generate more opportunities from the platform. In addition to providing services for ordering sports fields online, Arena-O also provides a Point of Sales feature and cashless payments by cooperating with non-cash payment partners such as OVO, Go-Pay, LinkAja, etc. So it is hoped that this service can help producer partners be more advanced and better. 


\subsection{Other Services}

In this study, what is meant by Other Services namely: classic industrial services that can be provided to consumers as a complement to the experience provided by the ecosystem through the platform. The Arena-O application will later be equipped with news features about sports as a complement and source of inspiration for consumers.

\subsection{Core Value Propositions}

In this study, what is meant by the Core Value Proposition namely: the main value that the platform wants to create for its core target. Arena-O's main vision is to help sports fans book sports fields quickly and easily as simple as booking movie tickets online. Then from the interview results, it is known that sports fans are a segment with an age range between 10-55 years which consists of various professions ranging from school students to professionals where the majority of these segments own and use smartphones for daily activities. So Arena-O's Core Value Propositions provides services for ordering sports fields through a smartphone application.

\subsection{Ancillary Value Propositions}

In this study, what is meant by the Ancillary Value Proposition namely: The secondary value that the platform wants to create. These are typically targeted to the same target segment of the core value proposition but can also be targeted to different segments. In the future, Arena-O wants to provide more services to sports field owners who want to rent out their land for outdoor events for the general public such as intimate weddings, birthday parties, etc. So that the owners of sports fields get more value, and consumers can easily rent a place that suits their needs.

\subsection{Infrastructure and Core Components}

In this study, what is meant by Infrastructure and Core Components namely: covering digital and physical assets, tangible components, which ensure the platform works, these components require effort and energy to run smoothly and coordinated. Taking into account the behavior of potential consumers, namely sports fans who prefer mobile applications rather than opening websites, Arena-O creates an Android application that can be downloaded on the Google Play Store and in the future will create an iOS application for consumers who use iPhone.

\subsection{Transactions}

In this study, what is meant by Transactions namely: these transactions occur between two entities in the ecosystem and consist of the exchange or transfer of ownership of currency or other stores of value (assets, money, tokens, credits), which provide elements of intangible value (such as reputation, trust, praise, likes, etc.), provide labor/jobs or allow access to resources. For the transaction process, initially the consumer or the tenant of the sports field opens the Arena-O application, then selects the appropriate sports field, then orders the date, time, and duration of the field. Then pay with the transfer method according to the results of interviews with sports field owners who want a cashless payment system. After finishing playing on the sports field, consumers can review the sports field as input for the owner of the sports field and a reference for other potential consumers.

\subsection{Channels \& Contexts}

In this study, what is meant by Channels \& Contexts namely: Every relationship that is born in context and transactions occurs better thanks to a controlled and designed context that develops into what we call channels. Arena-O is in the early stages of launching an application for Android users and then following an application for iOS users. Then there will be a share feature on social media to attract new potential customers to use Arena-O.

\subsection{Partners}

In this study, Partners namely: professional entities that seek to create additional professional value and collaborate with platform owners on a stronger relationship stage. For Arena-O, you can collaborate with institutions, both education and offices, to invite subscriptions to use Arena-O by offering special promos. For the payment system and recording of orders, Arena-O cooperates with the Point of Sales system provider. And lastly, to store media, whether images or data, you need a hosting provider and a domain so that consumers can use the Arena-O application.

\subsection{Peers Producers}

In this study, what is meant by Peer Producers namely: entities that are interested in providing value to the supply side of the ecosystem/market, looking for opportunities to improve their professionalism and hone their skills towards better performance. The producers for the Arena-O application are the owners of the sports field. Their sports fields will be displayed and ordered via the Arena-O application.

\subsection{Peers Consumers}

In this study, what is meant by Peer Consumers namely: entities that are interested in consuming, utilizing, accessing the value created through and on the platform. From the results of interviews with sports field owners, it 
can be seen that their consumers are sports fans with an age range of 10-55 years, ranging from school students to professionals, and the majority are male.

\section{Conclusions and Practical Implication \\ 5.1. Conclusion}

There are several things that need to be considered in setting up a technology startup when creating a mobile application. From the results of interviews with three sources, each representing producers, consumers and platform owners.

1. From the producer side, they want not only an application for ordering sports fields online but also to provide point of sales services, namely a sales recording system and a cashless payment system to facilitate transactions. The interview also shows that their consumers are sports fans aged 10-55 years, ranging from school children, students, and professionals and dominated by men.

2. From the consumer side, it is known that they prefer to use applications rather than opening websites to order sports fields. Then for the intensity of doing exercise is done twice a week.

3. From the platform owner's perspective, it is known that what the platform owner must provide is hosting, domain. Then must have a partner or partners to support the running of the business. Then platform owners can use Whatsapp and Instagram to reach their consumers.

\subsection{Managerial Implications}

The implications of this research can be a description of the Arena-O business model. From this research, researchers can find out the visualization of Arena-O's business processes from upstream to downstream. The following is a table of research implications:

Table 5.1. Managerial Implications

\begin{tabular}{|l|l|l|}
\hline \multicolumn{1}{|c|}{ Indicator } & \multicolumn{1}{|c|}{ Before research } & \multicolumn{1}{c|}{ After research } \\
\hline $\begin{array}{l}\text { Enabling } \\
\text { Services }\end{array}$ & $\begin{array}{l}\text { The application still only has a sports field } \\
\text { booking service, due to limited resources, and } \\
\text { is still in the early stages of the application. }\end{array}$ & $\begin{array}{l}\text { Develop application services for family tournaments, member } \\
\text { promos for monthly subscription customers, and provide } \\
\text { admin support to help consumers. }\end{array}$ \\
\hline $\begin{array}{l}\text { Other } \\
\text { Services }\end{array}$ & $\begin{array}{l}\text { For the initial stage of the application, in } \\
\text { addition to the application for ordering sports } \\
\text { fields, it will also develop the branding side on } \\
\text { Instagram social media. }\end{array}$ & $\begin{array}{l}\text { In the future, we will add sports news features to provide } \\
\text { sports inspiration to application users. }\end{array}$ \\
\hline & $\begin{array}{l}\text { Currently. partners focus of Arena-O is to } \\
\text { attract sports field owners to join Arena-O }\end{array}$ & $\begin{array}{l}\text { After getting many partners on sports fields, Arena-O's next } \\
\text { focus is to invite partners such as universities, schools, sports } \\
\text { clubs, institutions to use the Arena-O application. }\end{array}$ \\
\hline
\end{tabular}

The results of the implications of this research can develop in the future following technological developments and trends in society. It is hoped that Arena-O will be able to get many new customers and then get many repeat customers so that this application will continue to grow in the future.

\section{References}

Blank, S. (2010). Steve blank what's $s$ startup? first principles. Steve Blank. https://steveblank.com/2010/01/25/whats-a-startup-first-principles/

Bungin, B. (2007). Penelitian kualitatif: Komunikasi, ekonomi, kebijakan publik, dan ilmu sosial lainnya (Vol. 2). Jakarta: Kencana Prenada Media Group.

Clark, T., Osterwalder, A., \& Pigneur, Y. (2012). Business model you: A one-page method for reinventing your career. John Wiley \& Sons.

Ju, J., Kim, M.-S., \& Ahn, J.-H. (2016). Prototyping business models for IoT service. Procedia Computer Science, 91, 882-890. https://doi.org/10.1016/j.procs.2016.07.106

Kumar, V., Lahiri, A., \& Dogan, O. B. (2018). A strategic framework for a profitable business model in the sharing economy. Industrial Marketing Management, 69, 147-160. https://doi.org/10.1016/j.indmarman.2017.08.021

Qur'ani, H., \& Khairunnisa, R. (2018). Analisis bisnis model dengan pendekatan Business Model Canvas terhadap Usaha Mikro Kelas Menengah Laundry Papin Sukapura Telkom University. Almana: Jurnal Manajemen Dan Bisnis, 2(1), 79-86.

Sort, J. C., \& Nielsen, C. (2018). Using the business model canvas to improve investment processes. Journal of 
Research in Marketing and Entrepreneurship, 20(1), 10-33. https://doi.org/10.1108/JRME-11-2016-0048

Yusuf, A. M. (2016). Metode penelitian kuantitatif, kualitatif \& penelitian gabungan. Jakarta: Prenada Media Group.

Zuhri, F. S., \& Melinda, T. (2018). Business Model Canvas in Crackers Manufacturing Company. The Fifth International Conference on Entrepreneurship, 16-30. 